\title{
AN INVESTIGATION OF THE SENSITIVITY OF POLYMER-COATED SURFACE ACOUSTIC WAVE- BASED GAS SENSORS IN THE DETECTION OF VOLATILE ORGANIC COMPOUNDS
}

\author{
Aliza Aini Md Ralib* and Amirah Syahirah Syamsil OMar \\ Department of Electrical and Computer Engineering, Kulliyyah of Engineering, \\ International Islamic University of Malaysia, \\ Jalan Gombak, 53100, Kuala Lumpur, Malaysia \\ *Corresponding author: alizaaini@iium.edu.my
}

(Received: $3^{\text {rd }}$ August 2020; Accepted: $23^{\text {rd }}$ January 2021; Published on-line: $4^{\text {th }}$ July 2021)

\begin{abstract}
Surface acoustic wave sensors (SAWs) are excellent at detecting volatile organic compounds (VOCs) since a sensing layer can be created by spreading a thin film of material across the delay line. This critically enhances performance as it is sensitive to the physical phenomena of interest. This study aims to provide a thorough investigation of the sensitivity of polymer-coated SAW-based gas sensors to VOCs using simulations via the finite element method (FEM). As such, quartz was chosen as the piezoelectric substrate while polymeric materials were chosen as the sensing layers due to their high sensitivity, low energy consumption, short response time, performance at room temperature, and reversibility after exposure to an analyte. The polymeric materials chosen were: (1) polyisobutylene (PIB), (2) polydimethylsiloxane (PDMS), (3) polyisoprene (PIP), (4) polyimide (PI), and (5) phenylmethyldiphenylsilicone (OV25). The VOCs chosen for investigation were: (1) dichloromethane (DCM), (2) trichloroethylene (TCE), (3) 1,2dichloroethylene (DCE), and (4) carbon tetrachloride $\left(\mathrm{CCl}_{4}\right)$. The performance of each polymer-coated SAW sensor was evaluated in terms of frequency shift and sensitivity to each VOC in FEM simulations. Our study found that the PIB-coated sensor had the highest sensitivity $(4.0571 \mathrm{kHz} / \mathrm{ppm})$ to DCM vapor and good sensitivity $(45.257 \mathrm{kHz} / \mathrm{ppm})$ to TCE vapor. However, the performance of each polymer-coated sensor varied depending on the type of VOC being tested. As an example, while the OV25-coated sensor was more sensitive $(52.57 \mathrm{kHz} / \mathrm{ppm})$ than the PIB-coated sensor $(53.54 \mathrm{kHz} / \mathrm{ppm})$ to TCE vapor regardless of the concentration, the PIB-coated sensor was more sensitive to DCM vapor at both low $(4.06 \mathrm{kHz} / \mathrm{ppm})$ and high $(3.54 \mathrm{kHz} / \mathrm{ppm})$ concentrations than the OV25coated sensor. Therefore, the results of our FEM simulations indicate that polymer-coated SAW-based gas sensors are highly capable of self-powered VOC detection.
\end{abstract}

ABSTRAK: Sensor gelombang akustik permukaan (SAW) adalah sangat baik dalam mengesan sebatian organik meruap yang tidak stabil (VOCs), kerana lapisan pengesan dapat dihasilkan dengan melapis nipis bahan pada lapisan garis tunda. Cara ini dapat menambah baik prestasi kerana ianya sensitif kepada fenomena fizikal yang dituju. Kajian ini bertujuan bagi menyediakan kajian menyeluruh terhadap kesensitifan sensor gas berasaskan SAW bersalut polimer pada VOC menggunakan simulasi melalui kaedah unsur terhingga (FEM). Oleh itu, kuarza dipilih sebagai substrat piezoelektrik manakala bahan polimer dipilih sebagai lapisan penginderaan berdasarkan kepekaan tinggi, penggunaan tenaga rendah, respon masa singkat, prestasi suhu bilik, dan faktor keboleh-balikan setelah terdedah kepada analit. Bahan polimer yang dipilih adalah: (1) polisobutilena (PIB), (2) polidimethilsiloxana (PDMS), (3) polisoprena (PIP), (4) polimida (PI), dan (5) phenilmethildiphenilsilikon (OV25). VOC terpilih bagi kajian adalah: (1) diklorometana 
(DCM), (2) trikloretilena (TCE), (3) 1,2-dikloroetilena (DCE), dan (4) karbon tetraklorida $\left(\mathrm{CCl}_{4}\right)$. Prestasi setiap sensor SAW bersalut polimer dinilai berdasarkan peralihan frekuensi dan kesensitifan pada setiap VOC simulasi FEM. Dapatan kajian menunjukkan sensor bersalut-PIB mempunyai kesensitifan paling tinggi $(4.0571 \mathrm{kHz} / \mathrm{ppm})$ terhadap wap DCM dan kepekaan yang baik $(45.257 \mathrm{kHz} / \mathrm{ppm})$ terhadap wap TCE. Walau bagaimanapun, prestasi setiap sensor bersalut polimer adalah berbeza bergantung kepada jenis VOC yang sedang diuji. Sebagai contoh, sensor bersalut OV25 adalah lebih sensitif $(52,57 \mathrm{kHz} / \mathrm{ppm})$ daripada sensor bersalut PIB $(53,54 \mathrm{kHz} / \mathrm{ppm})$ pada wap TCE tanpa mengira kepekatan. Manakala sensor bersalut PIB lebih sensitif terhadap wap DCM pada kedua-dua kepekatan rendah $(4.06 \mathrm{kHz} / \mathrm{ppm})$ dan tinggi $(3.54 \mathrm{kHz} / \mathrm{ppm})$ daripada sensor bersalut-OV25. Oleh itu, hasil simulasi FEM menunjukkan bahawa sensor gas berasaskan SAW bersalut polimer adalah sangat berpotensi sebagai pengesan VOC berkuasa sendiri.

KEYWORDS: surface acoustic wave; gas sensor; polymer sensing layer; sensitivity; frequency shift

\section{INTRODUCTION}

Breath analysis has recently emerged as a new and improved diagnostic tool in health examinations with technical advantages, such as being non-invasive, painless, costeffective, user-friendly, easily repeatable, and offering real-time testing methods; over existing methods [1]. Current diagnostic methods involve complex, costly, and invasive procedures, such as blood and urine tests, endoscopy, biopsies, imaging etc.; to diagnose diseases. Moreover, some diagnostic imaging studies, such as MRIs, X-rays, and CT scans; cannot be repeated in a short period of time due to exposure to high amounts of radiation [2].

Breath analysis is a systematic review of the volatile organic compounds (VOCs) exhaled in human breath. Each exhaled VOC is a biomarker containing clinical information for disease diagnosis. Several studies have shown that certain exhaled VOCs are clinical biomarkers of metabolic disorders and other diseases [3]. Alkanes, for instance, are biomarkers of lung cancer while acetone is used to diagnose diabetes [4]. As such, various detection devices, such as piezoelectric sensors and optical sensors, have been created specifically for this purpose. A SAW-based gas sensor is a piezoelectric sensor that measures physical changes such as fluctuations in mass [5]. They are also widely used in medicine and research studies to examine human health via breath analysis. Therefore, this study chose to investigate SAW-based gas sensors as they are not only highly sensitive and offer faster disease detection but are environmentally friendly as well. The ability to introduce a sensing layer further enhances its performance in terms of sensitivity and selectivity as it enables mass loading that results in changes in acoustic wave velocity and resonant frequency [6]. This study aims to thoroughly investigate the performance of polymer-based sensing layers in SAW-based gas sensors through simulation via the finite element method (FEM). Previous studies have explored the usage of SAW-based and Quartz Crystal Microbalance gas sensors for electronic nose applications [7]. FEM simulation has also been used to measure the sensitivity of bulk acoustic wave sensor for breath analysis application [8]. However, the sensitivity and selectivity of SAW-based gas sensors to different types of VOCs warrants further investigation. Therefore, this study created simulations to test the ability of five different polymers in sensing four different VOCs in a SAW-based gas sensor. The performance of each polymer-coated sensor was evaluated in terms of frequency shift and sensitivity to each VOC. 


\section{DESIGN CONCEPT: SURFACE ACOUSTIC WAVE AND PIEZOELECTRICITY}

Piezoelectricity is the ability of some solid materials to generate electrical energy when subjected to mechanical stress. A piezoelectric transducer is basically a "crystal" sandwiched between two metal plates and compressed to generate electricity [9]. Direct piezoelectricity occurs when a piezoelectric material is compressed and flows through the metal plates to produce mechanical energy. Therefore, the crystal reacts to the pressure of the applied stress and converts it into electrical energy. Meanwhile, an inverse piezoelectric effect occurs when a crystal is deformed by the electrical energy applied and converts it to mechanical energy [9]. A SAW sensor consists of both input and output interdigital transducers (IDTs) on a piezoelectric substrate. A thin and highly sensitive layer, capable of changing the resonant frequency of the SAW sensor, is then placed between both the IDTs. Figure 1 shows the basic structure of a SAW sensor. The choice of piezoelectric substrate is not only important but varies according to the primary function of the sensor [10]. Popular choices of substrate materials include zinc oxide ( $\mathrm{ZnO})$, quartz, and lithium niobate $\left(\mathrm{LiNbO}_{3}\right)$ [10]. A SAW-based gas sensor is used to detect minute changes in surface mass caused by gas absorption by the sensing layer [9] that then causes the resonant frequency of the sensor to shift i.e., the higher the shift in resonant frequency, the higher the sensitivity of the sensor. Apart from the sensing layer, the type of material used to coat the substrate also affects sensor performance.

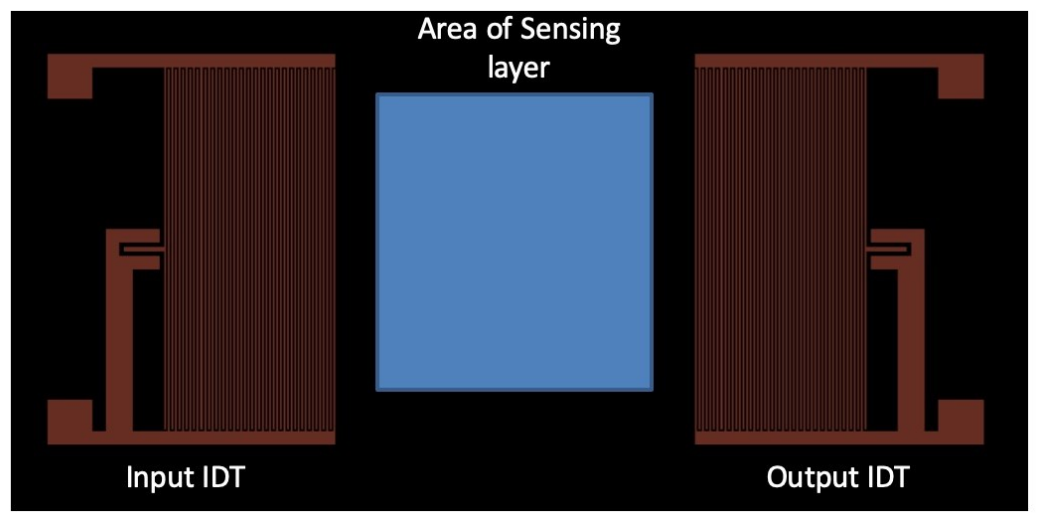

Fig. 1: Schematic diagram of a surface acoustic wave (SAW) sensor.

Resonant frequency, $f r$ is defined as the specific frequency of an acoustic wave oscillating at higher amplitudes. It can be calculated using Eq. (1) where, $\lambda$ is the wavelength and $v$ is the velocity of the acoustic wave. Based on these two parameters, a wavelength is a traveling wave that follows the dimensions of the IDTs [11].

$$
f=\frac{v}{\lambda}
$$

The absorption of gasses by the sensing layer changes its elemental properties, such as density, thickness, elastic modulus, and acoustic velocity, which causes a frequency shift in the SAW-based gas sensor. The changes in frequency due to the absorption of gases by nonpiezoelectric, non-conducting, isotropic thin polymer sensing layers are given below where, $\Delta f$ is the frequency shift, $h$ is the thickness of the polymer layer, $f_{0}$ is the operating frequency, $\rho$ is the density of the polymer layer, $k_{1}$ and $k_{2}$ are the constants of the substrate, and $\lambda$ and $\mu$ are the Lamé constants [12]. 


$$
\Delta f=\left(k_{1}+k_{2}\right) f_{0}^{2} h \rho-k_{2} f_{0}^{2} h\left[\frac{4 \mu}{v_{R}^{2}}\left(\frac{\lambda+\mu}{\lambda+2 \mu}\right)\right]
$$

The sensitivity of a SAW sensor is determined by the difference between the input and output measures. It is also can be determined by the amount of shift in resonant frequency and mass sensitivity as shown in Eq. (3) where, $c_{m}$ is the mass sensitivity coefficient independent of frequency, $h$ ' is the thickness of the coating containing gas molecules, and $\Delta \rho_{s}$ is the change in mass density due to absorption [13].

$$
\Delta f=-c_{m} f_{0}^{2} h^{\prime} \Delta \rho_{s}
$$

\section{SAW SENSOR SIMULATION VIA FINITE ELEMENT METHOD}

The SAW sensors were simulated using the FEM. As shown in Fig. 1, each SAW-based gas sensor consisted of an input IDT, a mass loading area, and an output IDT. With an acoustic wave velocity of $3159 \mathrm{~m} / \mathrm{s}$ [10], quartz was our choice of piezoelectric substrate. Based on Equation (1), the resonant frequency of the SAW sensors was $40 \mathrm{MHz}$. Aluminum electrodes, with a $\lambda / 4$-width and $800 \mathrm{~nm}$-thickness, were used as the IDTs. Three reflectors, with a width and spacing of $\lambda / 8$, were placed on either side of the sensors. Figure 2 shows a 2D model of the simulated SAW-based gas sensor while its physical parameters are detailed in Table 1.

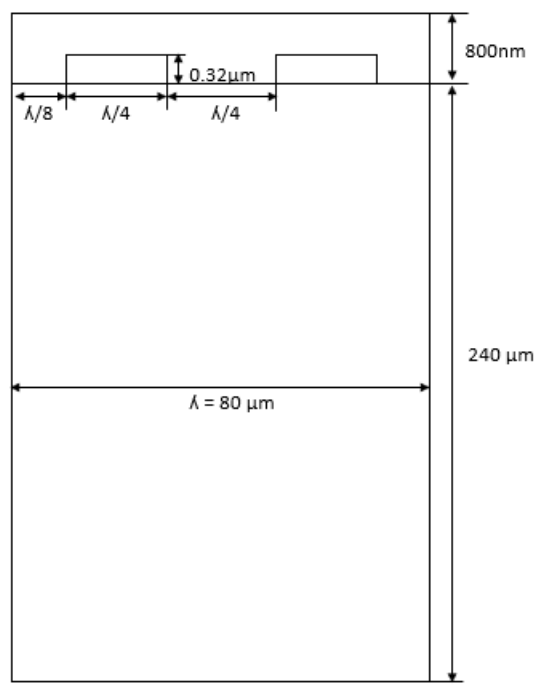

Fig. 2: 2D model of the simulated SAW-based gas sensor.

\subsection{Polymeric Sensing Layers}

Polymers are highly sensitive, making them an ideal choice of sensing layer. When exposed to VOCs, the sensing layer absorbs and desorbs these vapor analytes resulting in physical changes in mass and dielectrical properties that affect the resonant frequency, which is then converted into an electrical output signal [14]. Polymer-based SAW sensors for gasses are highly sensitive, have low energy consumption, short response times, and perform well at room temperature. Table 1 lists the polymers used in our FEM simulations: (1) polyisobutylene (PIB), (2) polydimethylsiloxane (PDMS), (3) polyisoprene (PIP), (4) polyimide (PI), and (5) phenylmethyldiphenylsilicone (OV25) as well as the physical parameters of the simulated SAW-based gas sensors. 
Table 1: Physical parameters of the simulated SAW-based gas sensors.

\begin{tabular}{ll}
\hline Parameter & Expression \\
\hline Substrate material & Quartz \\
\hline Resonant frequency & $47 \mathrm{MHz}$ \\
\hline IDTs material & Aluminum $(\mathrm{Al})$ \\
\hline Wavelength & $80 \mu \mathrm{m}$ \\
\hline Width & $20 \mu \mathrm{m}$ \\
\hline Sensing layer material & Polyisobutylene (PIB) \\
& Polydimethylsiloxane (PDMS) \\
& Polyisoprene (PIP) \\
& Polyimide (PI) \\
& Phenylmethyldiphenylsilicone (OV25) \\
& 800 nm \\
\hline Thickness & Dichloromethane (DCM) \\
\hline VOC vapor material & Trichloroethylene (TCE) \\
& Dichloroethylene (DCE) \\
& Carbon tetrachloride (CCl $\left.{ }_{4}\right)$ \\
\hline
\end{tabular}

\subsection{Volatile Organic Compounds (VOCs)}

A sensor's response depends on the interaction between the VOC vapors and the polymeric sensing layer. To better understand these interactions, as well as the transduction mechanism of the device, these responses should be comparable. It is well established that a SAW sensor coated with a permeable material will produce responses proportional to the partition coefficient, $\mathrm{K}$ [15]. An increase in sensing layer density indicates vapor absorption. In our FEM simulations, sensors are exposed to VOCs at room temperature and atmospheric pressure. Therefore, as a consequence of mass loading, the simulations will experience changes in the mechanical and electrical boundaries. Table 2 lists the VOCs used in our FEM simulations: (1) dichloromethane (DCM), (2) trichloroethylene (TCE), (3) 1,2dichloroethylene (DCE), and (4) carbon tetrachloride $\left(\mathrm{CCl}_{4}\right)$ as well as the critical parameters used to evaluate SAW-based gas sensor performance; partition coefficient $(K)$ and molar mass $(M)$.

Table 2: Parameters of the simulated VOCs used to calculate the density of vapors absorbed by the polymeric sensing layers

\begin{tabular}{ccc}
\hline Type of VOC & Partition coefficient, $\boldsymbol{K}$ & Molar Mass, $\boldsymbol{M}(\mathbf{g} / \mathbf{m o l})$ \\
\hline Dichloromethane (DCM) & $10^{1.4821}$ & 84.93 \\
Trichloroethylene (TCE) & $10^{2.3994}$ & 131.4 \\
Dichloroethylene (DCE) & $10^{1.9215}$ & 96.95 \\
\hline
\end{tabular}

\section{SAW SENSOR SIMULATION VIA FINITE ELEMENT METHOD}

The frequency shift is calculated by evaluating the eigenfrequency before and after sensing the absorbed vapors at different concentrations. Subtracting the output eigenfrequency value, obtained after exposure to a specific vapor concentration, from the input eigenfrequency value, obtained before exposure to a VOC, provides the frequency shift. Therefore, the frequency shift of a SAW sensor can be determined by dielectrically repeating this procedure [15]. In our FEM simulations, quartz was used as the piezoelectric substrate. Figure 3 shows the resonant frequency of the SAW-based gas sensor before exposure to any VOCs. This resonance is caused by constructive interference as most of the 
acoustic wave propagations occur on the surface and their amplitude decreases according to material depth [16].

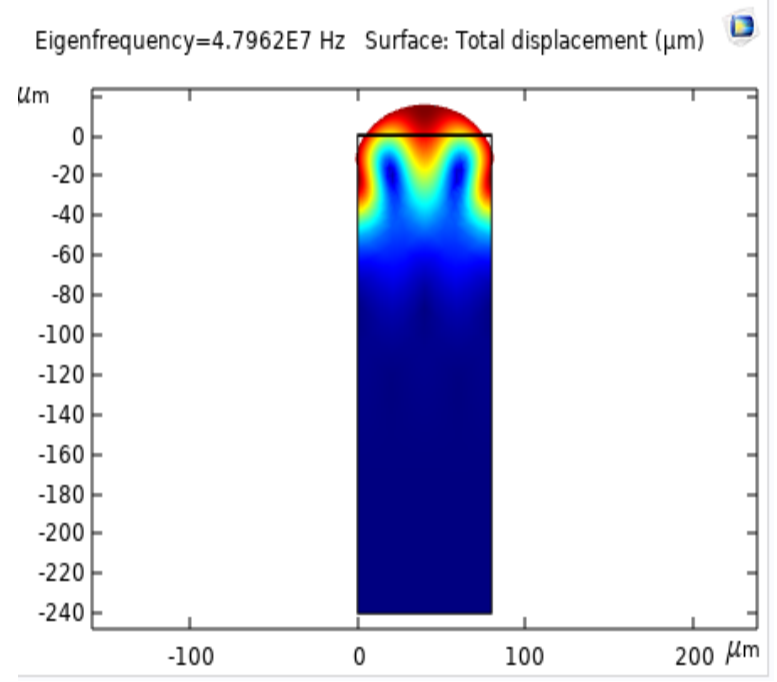

Fig. 3: 2D model of the simulated SAW-based gas sensor.

\subsection{SAW Sensor Sensitivity According to Polymer}

The five polymer-coated sensors were used to detect DCM vapor. Shifts in frequency were then calculated for analysis. The results of our FEM simulation for each polymer-VOC interaction are shown in Fig. 4. As frequency shift is affected by vapor concentration, the DCM vapor was set at concentrations of $500 \mathrm{ppm}$ to $3000 \mathrm{ppm}$. The PIB-coated sensor had the highest sensitivity $(4.0571 \mathrm{kHz} / \mathrm{ppm})$ followed by the OV25-coated sensor $(3.7143$ $\mathrm{kHz} / \mathrm{ppm}$ ). PIB is highly sensitive as it is highly permeable, thereby allowing quicker absorption, desorption, and reversibility post-vapor analyte exposure which is ideal for mass-sensitive sensors such as the SAW-based gas sensor [17].

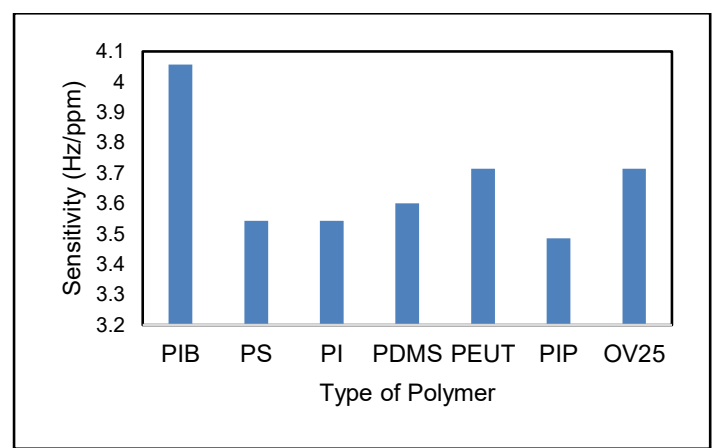

Fig. 4: The sensitivity of polymer-coated sensors to DCM vapor.

\subsection{SAW Sensor Sensitivity According to VOCs}

As it had the highest sensitivity, the PIB-coated sensor was used to detect each VOC which is measured by a downward shift in resonant frequency [15]. The frequency shifts, as a result of increased surface density caused by vapor absorption, of the PIB-coated sensor after exposure to DCM, TCE, DCE, and $\mathrm{CCl}_{4}$ vapors were calculated. As shown in Figure 5 (a), the higher the vapor concentration, the higher the density of vapor absorbed by the PIB-sensing layer, the higher the shift in resonant frequency. Figure 5(b) shows that the PIB-coated sensor had the highest sensitivity to TCE vapor $(45.257 \mathrm{kHz} / \mathrm{ppm})$ and lowest 
sensitivity to DCM vapor $(4.0571 \mathrm{kHz} / \mathrm{ppm})$. This indicated that the PIB-coated sensor had excellent selectivity towards TCE vapor.

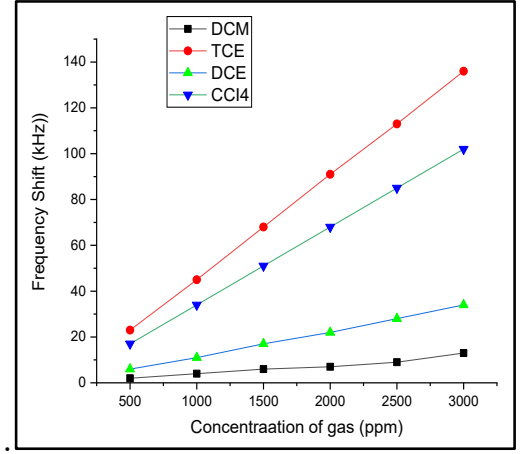

(a)

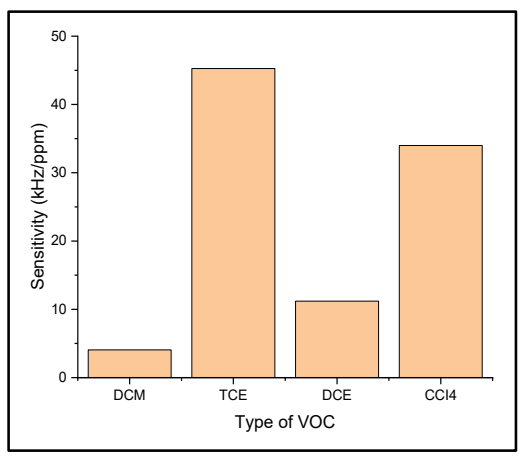

(b)

Fig. 5: PIB-coated sensor sensitivity to DCM, TCE, DCE, and $\mathrm{CCl}_{4}$ vapors. (a) Frequency shift according to vapor concentrations (b) PIB-coated sensor sensitivity according to type of VOC.

\subsection{SAW Sensor Sensitivity According to VOCs}

To further demonstrate this approach, the sensitivity of two polymeric sensing materials; PIB and OV25; to TCE, DCE, and DCM vapors was investigated. Quartz was maintained as the substrate material in this simulation. The sensor responses in relation to vapor concentrations were performed to determine the sensitivity of each polymer-vapor combination while individual sensor responses to various pairs of vapors would validate their sensitivity. Figures 6 and 7 show the responses of PIB- and OV25-coated sensors to TCE, DCE, and DCM vapors.

Figure 6 shows the frequency shifts of PIB- and OV25-coated sensors exposed to low concentrations of TCE and DCE vapors. The OV25-coated sensor had the highest sensitivity to both concentration in the range of $50 \mathrm{ppm}$ to $300 \mathrm{ppm}(52.57 \mathrm{kHz} / \mathrm{ppm})$ concentrations of TCE vapor in comparison to the PIB-sensing layer.

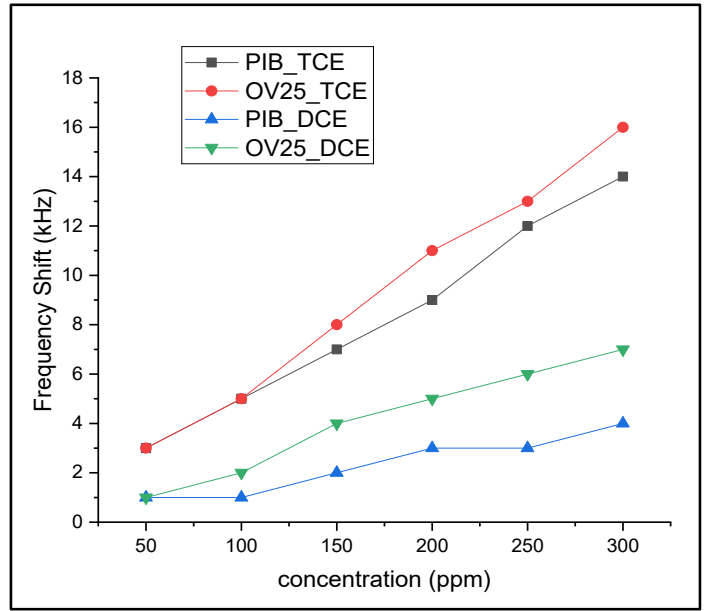

Fig. 6: Frequency shift results of the FEM simulations of PIB- and OV25-coated sensors exposed to concentrations of TCE and DCE vapors in the range of $50 \mathrm{ppm}$ to $300 \mathrm{ppm}$. 
DCM vapor was selected to evaluate the performance of PIB- and OV25-coated sensors as shown in Fig. 7. The PIB-sensing layer had marginally higher frequency shifts in reaction to both low $(4.06 \mathrm{kHz} / \mathrm{ppm})$ and high $(3.54 \mathrm{kHz} / \mathrm{ppm})$ concentrations of DCM vapor in comparison to the OV25-coated sensor. Figure 8 summarizes the sensitivity of both sensing layers to low (500 ppm to $3000 \mathrm{ppm})$ and high (3000 ppm to $5500 \mathrm{ppm})$ concentrations of TCE, DCE, and DCM vapors. The FEM simulations clearly indicate that frequency shifts and sensitivity vary according to the polymer-coating and type of VOC tested. Therefore, the choice of polymer-coating depends entirely on the VOC to be detected.

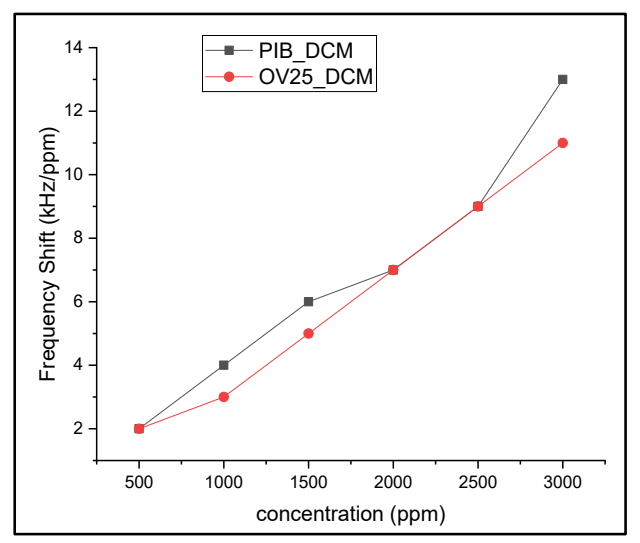

(a)

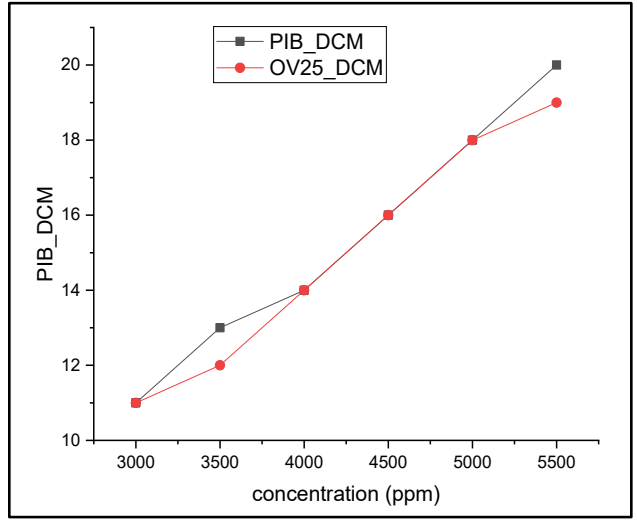

(b)

Fig. 7: Frequency shift results of the FEM simulations of PIB- and OV25-coated sensors exposed to (a) low concentration and (b) high concentrations of DCM vapor.

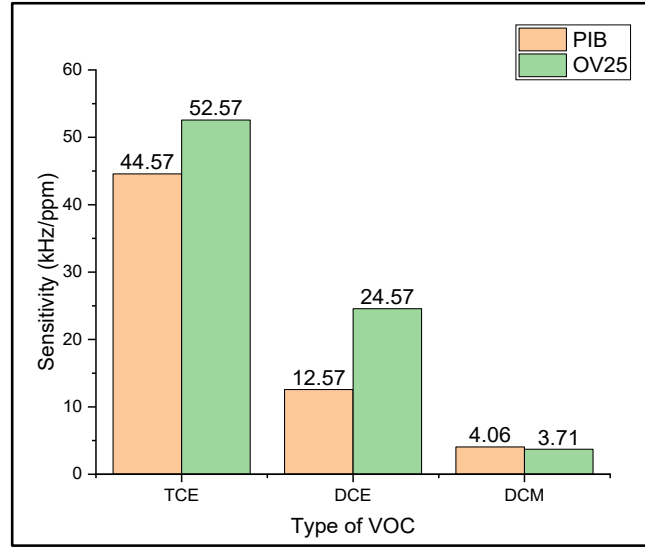

(a)

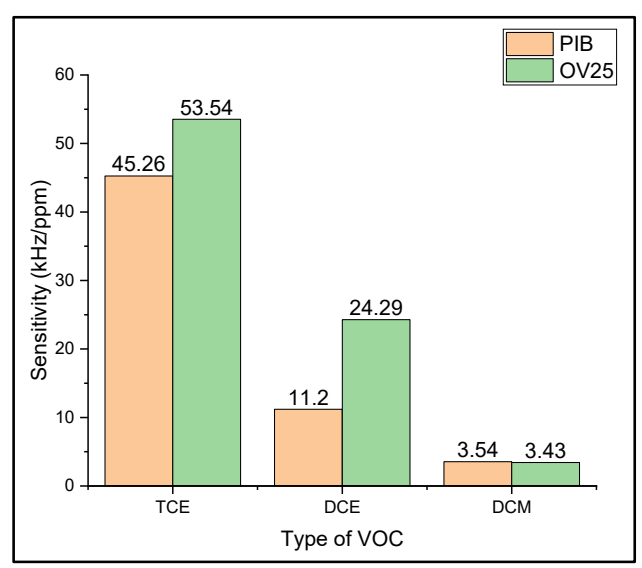

(b)

Fig. 8: Sensitivity results of the FEM simulations of PIB- and OV25-coated sensors exposed to (a) low concentration and (b) high concentrations of TCE, DCE, and DCM vapors.

Table 3 shows the comparison of simulation results with other previous work. The results show that the sensor is having higher shift in resonance frequency at high concentrations for both previous works and the current work. 
Table 3: Comparison of simulation results with other previous work

\begin{tabular}{|c|c|c|c|}
\hline Parameter & Lukose (2009) [12] & Zhao (2009) [15] & This work \\
\hline Substrate material & Quartz & ST-X Quartz & Quartz \\
\hline Resonant frequency & $303.79 \mathrm{MHz}$ & $158 \mathrm{MHz}$ & $47 \mathrm{MHz}$ \\
\hline IDTs material & Nickel & & Aluminum (Al) \\
\hline Sensing layer material & $\begin{array}{c}\text { Fluoroalco- } \\
\text { holpolysiloxane } \\
\text { (SXFA) film with } \\
\text { varies thickness of } \\
\text { h/lambda }(0-0.22)\end{array}$ & PIB, OV25 & PIB, PDMS, PI \\
\hline $\begin{array}{l}\text { VOC vapor material with } \\
\text { range of concentration }\end{array}$ & $\begin{array}{c}\text { DMMP } \\
\left(10-110 \mathrm{mg} / \mathrm{m}^{3}\right)\end{array}$ & $\begin{array}{c}\text { TCE, DCE } \\
\text { Low concentration } \\
\left(1-160 \mathrm{mg} / \mathrm{m}^{3}\right) \\
\text { High concentration } \\
\left(0.2-2.0 \mathrm{~g} / \mathrm{m}^{3}\right)\end{array}$ & $\begin{array}{l}\text { DCM, TCE, DCE } \\
\text { Low concentration } \\
\text { (500 to } 3000 \mathrm{ppm}) \\
\text { High concentration } \\
(3000 \text { to } 5500 \mathrm{ppm})\end{array}$ \\
\hline Frequency shift (Hz) & $220 \mathrm{~Hz}$ & $\begin{array}{l}\text { Low concentration } \\
(2-35 \mathrm{kHz}) \\
\text { High concentration } \\
(2-500 \mathrm{kHz})\end{array}$ & $\begin{array}{c}\text { Low concentration } \\
\quad(2-14 \mathrm{kHz}) \\
\text { High concentration } \\
\quad(1-20 \mathrm{kHz})\end{array}$ \\
\hline
\end{tabular}

\section{CONCLUSION}

The finite element method (FEM) simulations conducted by this study were able to successfully demonstrate the resonant frequency shifts and sensitivity of five polymeric materials: (1) polyisobutylene (PIB), (2) polydimethylsiloxane (PDMS), (3) polyisoprene (PIP), (4) polyimide (PI), and (5) phenylmethyldiphenylsilicone (OV25) to both low and high concentrations of four VOCs: (1) dichloromethane (DCM), (2) trichloroethylene (TCE), (3) 1,2-dichloroethylene (DCE), and (4) carbon tetrachloride $\left(\mathrm{CCl}_{4}\right)$. It is evident that resonant frequency shifts vary according to polymer-coated sensor and VOC interactions. The $800 \mathrm{~nm}$ thick PIB-sensing layer had the highest sensitivity (4.0571 $\mathrm{kHz} / \mathrm{ppm})$ to DCM vapor as well as good sensitivity $(45.257 \mathrm{kHz} / \mathrm{ppm})$ to TCE vapor. However, the choice of polymer-coating depends entirely on the VOC to be detected. The OV25-sensing layer had the highest sensitivity to both low $(52.57 \mathrm{kHz} / \mathrm{ppm})$ and high $(53.54$ $\mathrm{kHz} / \mathrm{ppm}$ ) concentrations of TCE vapor. The PIB-sensing layer had the highest sensitivity to both low $(4.06 \mathrm{kHz} / \mathrm{ppm})$ and high $(3.54 \mathrm{kHz} / \mathrm{ppm})$ concentrations of DCM vapor. It is evident that VOC concentrations also affect the sensitivity of the polymer-coated sensors. Therefore, the findings of this study indicate that polymer-coated SAW-based gas sensor are highly capable of self-powered VOC detection.

\section{ACKNOWLEDGEMENT}

This work was supported by the Ministry of Higher Education (MOHE) Malaysia under the Fundamental Research Grant Scheme (FRGS) (Grant No.: FRGS 17-032-0598).

\section{REFERENCES}

[1] Kim ID, Choi SJ, Kim SJ, Jang JS. (2015) Exhaled Breath Sensors. in: Kyung CM. (eds) Smart Sensors for Health and Environment Monitoring. KAIST Research Series. Springer, Dordrecht. https://doi.org/10.1007/978-94-017-9981-2_2

[2] Lee BC, Tward DJ, Mitra PP, Miller MI. (2018) On variational solutions for whole brain serial-section histology using a Sobolev prior in the computational anatomy random orbit model. PLoS Comput Biol 14(12): e1006610. https://doi.org/10.1371/ journal.pcbi.1006610 
[3] Wang C, Sahay P. (2009) Breath analysis using laser spectroscopic techniques: breathbiomarkers, spectral fingerprints, and detection limits. Sensors (Basel, Switzerland), 9(10): 8230-8262. https://doi.org/10.3390/s91008230

[4] Kim KH, Jahan SA, Kabir E. (2012) A review of breath analysis for diagnosis of human health. TrAC Trends in Analytical Chemistry, 33: 1-8.

[5] Afzal A, Iqbal N, Mujahid A, Schirhagl R. (2013) Advanced vapor recognition materials for selective and fast responsive surface acoustic wave sensors: A review. Analytica Chimica Acta, 787: 36-49.

[6] Aslam, M.Z.; Jeoti, V.; Karuppanan, S.; Malik, A.F.; Iqbal, A. FEM Analysis of Sezawa Mode SAW Sensor for VOC Based on CMOS Compatible $\mathrm{AlN} / \mathrm{SiO}_{2} / \mathrm{Si}$ Multilayer Structure. Sensors 2018, 18, 1687. https://doi.org/10.3390/s18061687

[7] Ralib AAM, Nordin AN, Salleh H. (2010) A comparative study on MEMS piezoelectric microgenerators. Microsystem Technologies, 16(10): 1673-1681.

[8] Arshak, K., Moore, E., Lyons, G.M., Harris, J. and Clifford, S. (2004), "A review of gas sensors employed in electronic nose applications", Sensor Review, Vol. 24 No. 2, pp. 181198. https://doi.org/10.1108/02602280410525977

[9] Hazadi AHF, Ralib AAM, Saidin N. (2018) Design and Simulation of Electroacoustic Sensor for exhaled breath analysis. in 2018 7th International Conference on Computer and Communication Engineering (ICCCE) pp. 388-391.

[10] Mujahid, A.; Dickert, F.L. Surface Acoustic Wave (SAW) for Chemical Sensing Applications of Recognition Layers. Sensors 2017, 17, 2716. https://doi.org/10.3390/s17122716

[11] Choi, K., Kim, H., Ali, K. et al. Hybrid Surface Acoustic Wave- Electrohydrodynamic Atomization (SAW-EHDA) For the Development of Functional Thin Films. Sci Rep 5, 15178 (2015). https://doi.org/10.1038/srep15178

[12] Lukose V, Nemade HB. (2019) Finite element simulation of one-port surface acoustic wave resonator with thick interdigital transducer for gas sensing. Microsystem Technologies, 25(2): 441-446.

[13] Haresh M., Pandya, (2010) Design and Modelling of Surface Acoustic Wave (SAW) Devices and Sensors", Ph.D. Thesis, Bharathiar University, Coimbatore: 8.

[14] Liu X, Cheng S, Liu H, Hu S, Zhang D, Ning H. (2012) A survey on gas sensing technology. Sensors, 12(7): 9635-9665.

[15] Zhao YG, Liu,M, Li DM, Li JJ, Niu JB. (2009) FEM modeling of SAW organic vapor sensors. Sensors and Actuators A: Physical, 154(1): 30-34.

[16] Johnson S, Shanmuganantham T. (2014) Design and analysis of SAW based MEMS gas sensor for the detection of volatile organic gases. Carbon, 119(5): 0-041316.

[17] Sayago I, Fernández MJ, Fontecha JL, Horrillo MC, Vera C, Obieta I, Bustero I. (2012) New sensitive layers for surface acoustic wave gas sensors based on polymer and carbon nanotube composites. Sensors and Actuators B: Chemical, 175: 67-72. 